\title{
FREEDOM OF ASSOCIATION UNDER THE CONTEXT OF VIETNAM'S PARTICIPATION IN THE COMPREHENSIVE AND PROGRESSIVE TRANS-PACIFIC PARTNERSHIP (CPTPP) AGREEMENT AND THE EU- VIETNAM FREE TRADE AGREEMENT (EVFTA)
}

\author{
Nguyen Duc Huu \\ Vietnam Trade Union University \\ DOI: 10.46609/IJSSER.2020.v05i11.008 URL: https://doi.org/10.46609/IJSSER.2020.v05i11.008
}

\begin{abstract}
Apart from participating in the World Trade Organization (WTO), joining CPTPP and EVFTA will be an opportunity for Vietnam to continue to improve our economic law institutions, of which, there is an institutional for socialist-oriented market economy, one of the three strategic breakthroughs that Vietnam has identified; support the process of innovation of growth model and restructuring of our economy, while giving us more opportunities to improve the business environment in a more open, transparent and predictable way, approaching advanced international standards, thereby promoting both domestic and foreign investment. New generation of free trade agreements such as CPTPP and EVFTA poses some challenges for Viet Nam in terms of labor. Currently, CPTPP and EVFTA is applying the labour standards outlined in the 1998 Declaration on fundamental principles and rights at work of the ILO. Accordingly, the content of freedom of association and collective negotiation of workers and employers is a new issue, which has been adjusted by Vietnamese law in accordance with the agreements when Vietnam fully participates in the contents of these agreements.
\end{abstract}

Keywords: Freedom of association, labour standards, CPTPP, EVFTA, Vietnam

\section{Introduction}

Under far-sighted leadership and with a strong sense of common goals among members of society, Viet Nam has achieved impressive economic development and helped millions of people escape poverty over the past thirty years. Based on the experience and lessons learned, Vietnam wishes to become a high middle income country by 2035. It's a very ambitious goal, but feasible.

With the establishment of the ASEAN Economic Community and accession to the EU-Vietnam Free Trade Agreement and new generation of free trade agreements, Vietnam is one of the few 


\section{International Journal of Social Science and Economic Research}

ISSN: $2455-8834$

Volume:05, Issue:11 "November 2020"

countries in the world that has good status to promote economic growth and strengthen necessary structural reforms for sustainable economic growth. Different economists will have different forecasts of future growth. But most observers agree that deeper global integration will increase growth potential significantly, and it will boost Vietnam's exports

However, in order to fully benefit from the new generation of free trade agreements, Vietnam will have to carry out important and widespread reforms with a view to improving the business environment, legal system and institutions that represent it. This article introduces an approach to freedom of associations from a historical perspective, international law, and development trends. Hopefully this is an important data, helping Vietnam's representative organizations to be proactive and integrate more deeply in the context of globalization

\section{Freedom of association from historical access}

Freedom of association (also known as free association as Marx often referred to as the community of individuals associated with freedom) is the relationship between individuals without a state, social class or institutions that represent it. In the context, individuals do not have production materials, and don't access to production facilities, such individuals have the freedom to associate (without being restricted by social conditions) to create and reproduce their working conditions. Mark considered this a defining characteristic of a fully developed communist society.

The concept of freedom of association becomes clearer when associated with the concept of the proletariat. The proletarian are people who have no assets and no means of production, and therefore to survive, they sell the only thing they have (labor) to those who have means of production. The existence of individuals deprived of property, lost livelihoods, allows capitalists to find the market in which they exchange wages and labor by accumulation of capital (surplus value) of the Bourgeoisie. (3)

The relationship between the proletarian and the employer is a compulsory relationship in which workers to survive, they only have to sell their labor in exchange for wages, ensuring survival. The proletarian puts its actual activity at the will of the buyer (owner) in the relationship of domination and exploitation. Freedom of association is a form of society created to allow individuals to decide their own destiny, in order to end a class society.

Lawmakers said that freedom of association must have an immediate role in the struggle for the proletariat for a new society and against the ruling class. So they promote a social revolution to abolish state, private property. They identified the state as the main sponsor of personal property (through the repressive apparatus: police, justice), so the abolition of the state was their main goal. 


\section{International Journal of Social Science and Economic Research}

ISSN: $2455-8834$

Volume:05, Issue:11 "November 2020"

In terms of free association, there is a difference between the proletarians. Mikhail Bakunin argues that liberal association has a function as a maxim: "Each person depends on his or her abilities, each depending on his actions". In contrast, liberal communists (such as Peter Kropotkin, Carlo Cafiero and ErricoMalatesta) argued that freedom of association should operate "according to their needs" (5-7). Liberal communists argued that work-based remuneration required the individuals involved to be subject to a different mechanism, and that the mechanism was forced a necessary representative or ruling class, and even could bring in wages. They also argue that if any work is done, it is essential and important. There is no quantative aspect to compare between them and everything created involves something necessary for the contribution of all members of the same system. Therefore there is no fair standard in comparing one person's work with another where it must be shared generally with all members.

Marxian and communist socialists in general differed from liberals by claiming that there must be an intermediate period between capitalist and liberal- association. But there are many differences between different Marxist trends. Marxist views on this transition period range from"expansion of state-owned production facilities". Thus, Marx's journals raised three basic trends: (i) democratic socialism, (ii) orthodox Marxism, and (iii) Liberal Marxism.

Democratic socialists (such as Eduard Bernstein and Karl Kautsky) argued that the advent of associated freedoms would gradually pass reforms of elected representatives in a democratic country. Lenin (such as Lenin and Trotsky) argued that it would only happen after seizing power through a coup or political revolution. The content of these reforms, for both democratic socialism and Leninism, was the transfer of personal property into the hands of the state. This would cause the rest of society to lose production facilities, as in capitalism, but it would be against the Bourgeoisie and direct society towards future freedoms. (8-11)

Scholars who support freedom of association (e.g. Anton Pannekoek, Otto Rühle, Herman Gorter and Rosa Luxemburg) often claim that the state cannot move towards free association because it can only act within the framework of capitalism itself. Most liberal Marxists argue that free associations can only be achieved through direct workers' activities, creating workers councils (operating under direct democracy)to gain means of production and abolish the state during a social revolution. (4)

Sociologists consider a free association in which freedom of association is characteristic of developed socialism. A free association would replace the state machine in socialism; The role of this association will direct the production and management processes. This is in contrast to the state in non-socialist society and capitalism, which is the government towards the people through forced action. The right of freedom of association represents an organization that coordinates economic activity related to administrative decision-making to meet the needs of the community. 


\section{International Journal of Social Science and Economic Research}

ISSN: $2455-8834$

Volume:05, Issue:11 "November 2020"

Sociologists consider this to be a defining factor for developed socialism; However many sociologists argue that such arrangements will follow the transition of economic and social development, such as market socialism.

On this day, many critics argue that freedom of association is often considered uimaginable or too abstract to direct a transformed society. However, it is judged by current trends and is seen as a fundamental principle in the relationship between the world's politicians.

\section{Freedom of union in accordance with applicable international law}

At the international level, freedom of union is protected primarily by multilateral treaties of the United Nations and the International Labour Organization.

Within the framework of the United Nations, freedom of association is expressed and guaranteed by important documents on human rights in general and workers' rights in particular. First, we must mention a recommending text, the 1948 Worldwide Declaration of Human Rights. Although it is not legally binding, this text can be seen as a legal doctrine and as the basis for the development of international legal documents on basic human rights, including freedom of association. (12)

In the labour-related rights group as noted in Article 23 of the manifesto, the right of freedom association is seen as an inseparable and indisputable right of workers. Clause 4, Article 23 stipulates: "Everyone has the right, along with others, to form trade unions or to join trade unions to protect their interests." (12)

In order to ensure the international legal validity of the above-mentioned freedoms, the United Nations has a series of conventions, including those that compel member states, when ratification the convention have to respect and facilitate all workers to participate, to form trade unions to protect their interests in industrial relations with employers.

Article 22, Clause 1 of the International Conventions on Civil and Political Rights of 1961 stipulates: "All men have the right to form association freely with others, including the right to form and join trade unions to protect their interests." At the same time as this Convention, Article 8, Clause 1 of the International Conventions on Economic, Social and Cultural Rights of 1962 also recognizes the freedom of association of all people. Accordingly, "The Member State of the Convention is committed to ensure the rights of all people to establish and join the trade unions of their choice, in order to promote and protect their economic and social interests, on the condition that they are subject only to the statutes of that trade union organization." (16) 


\section{International Journal of Social Science and Economic Research}

ISSN: $2455-8834$

Volume:05, Issue:11 "November 2020"

As such, both of the above-mentioned conventions allow the implementation of freedom of association in an unlimited way, except where the laws of the Member State provide restrictions on certain subjects, for the purpose of ensuring a democratic society, for the benefit of, national security and public order or for the purpose of protecting the rights and freedoms of others.

In addition to these two legally valid international documents, in 1990, the United Nations also launched an additional convention in the field of labor, aimed at protecting the rights of migrant workers. In this convention, the trade union rights of migrant workers on the territory of the Member State are also guaranteed the same as the rights of workers in the country. With article 7 provisions on "protection from discrimination" between workers of different nationalities, the 1990 United Nations Convention on the Protection of Migrant Workers and Their Family Members has forced Member States to ensure the freedom of association of foreign workers as the rights of domestic workers. In other words, this Convention has also indirectly recognized the freedom of all workers on the territory of the Member State. Article 26 of the Convention states: " Members countries recognizes the right of migrant workers to participate in meetings and activities of trade unions and other legitimate unions, in order to protect the rights and interests of the economy, culture, society and other rights, in accordance with the regulations of the above-mentioned organizations" This right is expressly defined in Article 40 of the same Convention: "Migrant workers have the right, together with others, to form association and trade unions in their country where they are working in order to implement and protect their economic, cultural, social and other interests." (11-13-14)

Thus, in accordance with international documents of the United Nations, for the purpose of ensuring their economic, cultural and social interests, all workers, including foreign workers, have the right to form and join trade unions of their choice.

In addition to the United Nations, workers' freedom of association has always been the center point which is protected by the International Labour Organization. Article 2, Convention 87 on the freedom to associate and protect trade union rights of the International Labour Organization (1948) stipulates: "All workers and employers have the right to establish and join organizations of their choice provided that they comply with the Charter of such organizations." (20)

As such, workers' freedom of association, according to the International Labour Organization, also includes the right to form and join trade unions of their choice. That is, workers can form various unions in one labor facility. On that basis, other workers have the freedom to choose to join one union, or another to protect their interests in the best way.

In order to ensure that this right is implemented thoroughly, Article 1 of Convention 98 of the International Labour Organization on the Right to Organize and Collective Labour and related 


\section{International Journal of Social Science and Economic Research}

ISSN: $2455-8834$

Volume:05, Issue:11 "November 2020"

agreements (1949) 5 stipulates: "Workers must enjoy appropriate protection against all discriminatory acts in order to infringe upon freedom of association in the field of labor". This Regulation is considered as a regulation aimed at developing and concretizing the principles and provisions of Convention 87 on freedom of association mentioned above. (13-15)

Thus, we see, Convention 87 and 98 clearly define the obligations of member states in ensuring the principles of freedom of association, in order to ensure the right to participate and establish trade unions of all workers. Accordingly, the Member State of the Conventions must empower all workers to establish and join trade union organizations of their choice. Countries, in fact and in legal documents, must ensure that they avoid infringing on the freedom of association and the implementation of this right by workers. In addition, countries must take necessary measures to ensure that workers have the right to freedom of association, avoid discriminatory acts for the reasons of workers participating in and trade unions establishment.

In relation to migrant workers, the International Labour Organization also has conventions to ensure the rights of workers of this subject. Article 6, Convention 97 on migrant workers (1949) stipulates: "The Member Countries of the Convention commit to apply, regardless of nationality of the employee (...) the right to join trade unions and inherit the benefits of collective labor agreements." However, in order to enjoy the above undiscrimination, migrant workers must be allowed to legally reside on the territory of the home country. This Convention was further developed by Convention 143 on migrant workers (1975) Article 10, Convention 143 stipulating: "Migrant workers must enjoy equal rights of opportunity and treatment, especially in rights relating to trade unions, individual and collective freedoms when they legally reside in the territory of the receiving country." (17-18)

In addition to the Conventions of compulsory legal validity for Ratification by Member Countries, the International Labour Organization also has declarations and recommendations for all Member Countries of the International Labour Organization to protect the unlimited freedom of association of workers. For example, the 1998 Declaration on fundamental principles and rights at work defines the obligation of member countries of the International Labour Organization (including countries that do not ratificate relevant convention of freedoms association) to respect workers' freedom of association. Thus, although it does not participate in and ratificate conventions of the International Organization for Freedom of Association, at least, the Member Countries of this Organization must ensure that all workers have the right to participate and form trade unions.

In France, the Constitution guarantees that "a person can protect rights and interests through trade union activity and may belong to the union of their choice' (Const. France,1958). Similarly, the constitution in Nicaragua stipulates that "Voluntary workers in unions, constituted in an 


\section{International Journal of Social Science and Economic Research}

ISSN: $2455-8834$

Volume:05, Issue:11 "November 2020"

organization in accordance with the provisions of law. No worker is obliged to belong to a Union or an organization to which they are dependent. Workers, are recognized and respected in the traditional rights of trade unions". (Const. Nicaragua, Article 87). (4-5)

Article 19 of the Indian Constitution declares that "a citizen will have the right to form the association or social organizations of their choice". The Constitution further asserts that "no law may affect the State's policy on ensuring the above principles (Const. India, 1949 [amended to 2012], Article 19 and 31). (5)

In Indonesia, the Constitution does not specifically mention the right to associate, but guarantees that people have the right to freedom of association, assembly and express (Const. Indonesia, 1945 [amended to 2002], Article 28). Enterprises need to establish standards in alternative industrial relations for trade unions and collective negotiation. This will be based on the selforganization of workers and representative institutions. An example of this is the regulation of multinational companies relating to workers' unions through the protocol on freedom of association and representation institutions (5-6)

\section{Protocol on freedom of association and representation institutions in Indonesia}

On June 6, 2011, a decree on freedom of association was signed by Indonesian trade unions, Indonesian sports employers and multinational sports brands including Adidas, Nike, Puma, Pentland, New Balance and Asics. This provides these companies an instruction tool about how to remain and respect workers' rights

- Join together in trade unions and collective negotiates.

- Pay deserving wages and better working conditions.

- The agreement covers areas of implementation such as trade union workers;

- Do not assault trade union officials and members;

- A commitment not to interfere with employers and trade union activities;

- The provision of access to professional trade union officials from outside the factory;

Rights to facilities for a labor union in the workplace and an obligation to employers to engage in collective negotiation with union workers.

This protocol is binding on all parties at all manufacturing plants. Goods in the footwear and garment supply chain of Sports Brands are signed in Indonesia as a standard for compliance 


\section{International Journal of Social Science and Economic Research}

ISSN: $2455-8834$

Volume:05, Issue:11 "November 2020"

with their local policies. Providers are obliged to disseminate the contents of this protocol. The implementation of the protocol will be periodically reviewed among

stakeholders representing sports brands, trade unions and supply companies.

Source: Indonesian Supreme Court and ILO improving the capacity of industrial relations court judges

\section{Implementation of freedom of association - opportunities and challenges in the conditions for Vietnam to join CPTPP, EVFTA}

Industrial Revolution 4.0 and FTA will accelerate changes in the economy and labor market. In general, we can hope that Industrial Revolution 4.0 and FTA have a positive potential to facilitate the structural transformation of Vietnam's economy and also improve the productivity and profile of industries of the country.

CPTPP and EVFTA, after being approved, will bring strong economic benefits to Vietnam, in the form of price competition of Vietnamese exports in major foreign markets and high FDI capital, drive economic growth and create millions of jobs, both small and medium-sized. At the same time, the technological changes symbolized by the Industrial Revolution 4.0 will deeply restructure the nature of work - both quantity and quality - in production and services. ILO research shows that technological changes will affect virtually all sectors, especially manufacturing industries. For example, the ILO estimates that 86 percent of all workers in Vietnam's garment, textile and footwear industries may face a high risk of automation in the future. Industrial Revolution 4.0 will destroy some jobs but at the same time create new types of jobs. This is a complex challenge that individual workers are not prepared to deal with. The individual worker cannot foresee which jobs will disappear and what new skills will be required in the future. Individual workers should not be left alone to find new jobs, as they lose their jobs due to structural and technological changes.

\section{Strongly reforming the role of the Vietnamese trade union}

With Innovation and deeper global integration, unions have made some adjustments to their functions, with a greater emphasis on expressing workers' power through collective bargaining. However, some gaps remain. There have been more than 6,000 strikes since the mid-1990s and all of them are spontaneous strikes, not initiated by trade unions. This is a clear indication that workers do not feel their rights and concerns are addressed and that the process is set up to address issues that are not working properly. (25) 


\section{International Journal of Social Science and Economic Research}

ISSN: $2455-8834$

Volume:05, Issue:11 "November 2020"

Not surprisingly, in Vietnam, trade union leaders in the workplace are senior managers of businesses, which is unacceptable in most countries in the world today. Union rights are workers' rights and unions are organizations of workers, without the intervention of employers. In order to comply with the requirements of CPTPP, EVFTA and more importantly, fulfill Vietnam's obligations as an ILO member country, changes are needed.

Vietnamese trade union has adopted new ways to organize workers in different regions and sectors. Previously, superior trade unions only approached the employer or manager of a company, asking the business to form a grassroots union. Once agreed, employers only form unions, often consisting of senior or middle managers, without the participation of a majority of workers. Recently, many trade unions now have a bottom-up approach to organizing workers. This means union leaders meet workers, explain what trade unions protect and benefits can offer and why workers need unions. In this way, unions become organizations of workers, not just another administrative body in the workplace.

In addition, some unions in industrial zones try to negotiate with many employers for better wages and working conditions than the legal minimum. These are very active developments. And in almost all market economies, this is what and how unions operate.

CPTPP and EVFTA require Vietnam to respect and promote the 1998 ILO Declaration, especially Convention 87 on freedom of association and Convention 98 on the right to collective bargaining. In short, it requires unions to be unions - in other words, it requires unions to be organizations of workers, since they are in most of the member countries of the ILO. This presents a golden opportunity for the unions under sponsorship of the VGCL to modernize their organization and functions to better express of workers' voices. (26)

Union rights are the rights of workers. In most ILO member countries, there are legal provisions that ensure the independence of the union from the employer, from interference or discrimination by the employer, and the right to self-control of trade union in managing of their own internal affairs, free from undue administrative interference, in accordance with rules set by national law and consistent with international labor standards. And those are the universal rules and principles of trade union and industrial relations, embodied in the 1998 ILO Declaration, required by the CPTPP and EVFTA (26).

\section{Completing the labor law system}

The Government has revised the Labor Code, as required by CPTPP and EVFTA in May 2019. Industrial relations chapters are not the key only to CPTPP and EVFTA but also because the overall goal is modernizing the way of working that is regulated in modern Vietnam. 


\section{International Journal of Social Science and Economic Research}

ISSN: $2455-8834$

Volume:05, Issue:11 "November 2020"

In a modern market economy, the conditions of workers, including wages, are determined through social dialogue and collective bargaining between workers' representatives and employers, Empowered and regulated by industry-related laws and regulations. This is a weakness of the existing Labor Code, which will have to improve its consistency with the 1998 ILO Declaration. During the revision, consideration should also be given to ratification of Conventions 98 and 87, since it provides a general principle based on which modern industrial relations are built up in most of the ILO member countries. However, there are many important issues that will affect businesses, workers and society as a whole, including employment contracts, discrimination, retirement age, wages and working hours. (27)

In that context, the importance of the full participation of trade unions, business representatives and other stakeholders throughout the Labor Code revision process. Whether or not the labor law reform is successful depends on workers' need for better protection and security, and the flexible needs of businesses can be met in a balanced manner. Balancing the needs of workers and employers is only possible when their representatives are involved in the process.

\section{CONCLUSION}

Freedom of association is a common guiding principle of modern industrial relations regardless of the stages of economic development - it is the foundation of industrial relations not only in the developed countries, but also in low-income country. These are basic human and labor rights, recognized by all member countries of the ILO system and United Nations. No one wants to see fragmented and weak unions. As we have seen from the experience of Cambodia and Indonesia, the rise of competitive and fragmented unions is not good for protecting workers 'rights and enhancing workers' interests, nor is it good for business efficiency.

Transitions to industrial relations based on freedom of association can be managed and coordinated to create an industrial relations system with a higher degree of socio-political stability. And I believe that Vietnam has all the conditions to manage the transition to industrial relations based on freedom of association with the support of social partners between the Vietnam General Confederation of Labor (VGCL) and Vietnam Chamber of Commerce and Industry (VCCI) under the leadership of the Party. International experience shows that effective unions contribute to social and political stability by including workers' voices in policy-making that affect the world of workers and workers, and at the same time contribute to shared prosperity by collective bargaining and social dialogue. There is a lot of global research showing statistical evidence for a positive association between trade unions and industrial relations, shared prosperity and social stability. 
International Journal of Social Science and Economic Research

ISSN: 2455-8834

Volume:05, Issue:11 "November 2020"

Deeper integration into the global economy tends to widen the gap between different economic sectors and increase volatility in a society, which can threaten long term sustainable and social cohesion of economic development. Therefore, ensuring freedom of association and building an effective representation institution can minimize the negative effects of globalization and maintain social harmony.

\section{References}

1. Aaronson, Susan Ariel and Michele Rioux. 2008. Striking a Proper Match? Strategies to Link Trade Agreements and Real Labor Rights Improvements." Presentation at the Humanizing Trade conference. Montreal, Quebec. April 7.

2. Ali, Jasim. 2009. "Bahrain's labor market shortcomings." Gulf News. August 16. Americas Watch Committee. 1990. "Human Rights in Mexico: A Policy of Impunity.” New York: Human Rights Watch.

3. Bush, George W. 2008. "Opening New Markets and Expanding Opportunities Through Free Trade.” Washington DC: The White House. Business Roundtable. 2006. "U.S.-Panama Free Trade Agreement (FTA): An Opportunity to Expand Trade and Investment Liberalization in Central America." Issue Brief. Washington, DC. Committee on Ways and Means. 2004. Serial No. 108-47. Congress Session: 108-2 (2004). July 7.

4. Compa, Lance. 2005. "Assessing Assessments: A Survey of Efforts to Measure Countries' Compliance with Freedom of Association Standards." Comparative Labor Law and policy Journal. Vol. 24:283-320.

5. Congressional Budget Office. 2003. "The Effects of NAFTA on U.S.-Mexican Trade and GDP." Washington DC. Cooper, William. 2006. "Free Trade Agreements: Impact on U.S.Trade and Implications for U.S.Trade Policy." Congressional Research Service.

6. Hornbeck, J.F. 2005. "The Proposed U.S.-Panama Free Trade Agreement." A Report to Congress. Washington DC: Congressional Research Service.

7. Hornbeck, J.F. 2008. "The Proposed U.S.-Panama Free Trade Agreement.” A Report to Congress. Washington DC: Congressional Research Service. Updated January 18, 2008. Human Rights Watch. 1993. "Letter to President Clinton Urging NAFTA Summit on Human Rights.” Washington DC. October 1.

8. Inter-American Development Bank. 2005. "The Labor Dimension in Central America and the Dominican Republic: Building on Progress: Strengthening Compliance and Enhancing 


\section{International Journal of Social Science and Economic Research}

ISSN: 2455-8834

Volume:05, Issue:11 "November 2020"

Capacity." Report prepared by the Vice Ministers for Trade and Labor in DR-CAFTA countries.

9. International Confederation of Free Trade Unions. 2003. "Internationally Recognized Core Labor Standards in Chile." Report for the WTO General Council Review of the Trade Policies of Chile. December 2 and 4. http://www.icftu.org/www/pdf/Chile\%20report.pdf International Labour Office. Committee on Freedom of Association. 2006. "Complaint against the Government of Morocco presented by Aircraft Engineers International (AEI)" Report No. 342, Case(s) No(s). 2455.

10. International Labour Organization. 2000. Labour Practices in the Footwear, Leather, Textile, and Clothing Industries. Geneva: International Labor Office.

11. International Labour Organization. 2002. "Reports and documents submitted to the Conference" http://www.ilo.org/public/english/standards/relm/ilc/ilc90/reports.htm International Labour Office 2003. "Fundamental Principles and Rights at Work: A Labour Law Study (Costa Rica, El Salvador, Guatemala, Honduras, Nicaragua)." Geneva, Switzerland: ILO.

12. International Labour Organization. 2004. "National Labour Law Profile: Jordan." http://www.ilo.org/public/english/dialogue/ifpdial/info/national/jo.htm International Labour Office 2003. "Fundamental Principles and Rights at Work: A Labour Law Study (Costa Rica, El Salvador, Guatemala, Honduras, Nicaragua).” Geneva, Switzerland:

13. ILO. International Labour Office. 2005. "A Global Alliance Against Forced Labour: Global Report under the Follow-up to the ILO Declaration on Fundamental Principles and rights at Work 2005.” International Labour Conference. 93rd Session 2005. Geneva,

14. ILO. International Labour Office. 2006. "Strategies and Practice for Labour Inspection." Geneva: ILO.http://www.ilo.org/wcmsp5/groups/public/---ed_norm/--relconf/documents/meetingdocument/wcms_gb_297_esp_3_en.pdf International Labour Office. 2006. "Decent Work Country Programme: Jordan."

15. http://www.ilo.org/public/english/bureau/program/dwcp/download/jordan.pdf International Labour Organization. 2006. Decent Work Pilot Programme Country Brief: Morocco.

16. http://www.ilo.org/public/english/bureau/program/dwcp/download/jordan.pdf International Labour Organization. 2006a. "Committee of Experts on the Application of Conventions and Recommendations General Surveys: Labour Inspection.” Geneva: ILO. 


\section{International Journal of Social Science and Economic Research}

ISSN: $2455-8834$

Volume:05, Issue:11 "November 2020"

17. International Labour Organization. 2006b. 'ILO calls for 'Ambitious Reforms' in Labour Inspection," Geneva: ILO. November 16.

18. http://www.ilo.org/global/About_the_ILO/Media_and_public_information/Press_releases/la ng-- en/WCMS_077640/index.htm\#2 International Labour Organization. 2006c. "Decent Work Pilot Programme. Country Brief: Panama.” Geneva, ILO.

19. http://www.ilo.org/public/english/bureau/dwpp/download/panama/countrybriefpa.pdf International Labour Office. 2008 International Labor Office (350th Report of the Committee on Freedom of Association). Geneva, Switzerland. International Labour Office. 2008. "Measurement of decent work, Discussion paper for the Tripartite Meeting of Experts on the Measurement of Decent Work." Geneva: ILO.

20. International Labour Office. 2008. "Resolutions Concerning the Measurement of Decent Work and Indicators of Labour Underutilization."

21. ILO Resolution. Adopted by the Eighteenth International Conference of Labour Statisticians (November-December 2008). Geneva: ILO. 66 International Labour Office. 2008.

"Resolutions Statistics of Child Labour."

22. ILO Resolution. Adopted by the Eighteenth International Conference of Labour Statisticians (NovemberDecember 2008). Geneva: ILO. International Labour Office. 2009. "Ratification and Promotion of Fundamental ILO Conventions." Geneva: ILO

23. International Trade Union Confederation. 2010. "El Salvador: Appalling Situation in the Export Processing Zones.” Brussels. February 10.

24. International Labour Organization (ILO) (2012) Indonesian Supreme Court and ILO improving the capacity of industrial relations court judges. 9 May

25. https://www.ilo.org/hanoi/Informationresources/Publicinformation/newsitems/WCMS 7105 43/lang--vi/index.htm

26. https://www.ilo.org/wcmsp5/groups/public/---asia/---ro-bangkok/---ilohanoi/documents/publication/wcms 144537.pdf

27. https://www.ilo.org/hanoi/Informationresources/Publicinformation/newsitems/WCMS 7021 94/lang--en/index.htm

28. https://www.ilo.org/hanoi/Whatwedo/Eventsandmeetings/WCMS 717961/lang-vi/index.htm 